\title{
Comparison of Child Adoption from Perspective of Islamic Law, Western Law, and Customary Law
}

\author{
Suyatno,S.H,M.Hum \\ Doctorate Candidate at Law Faculty, Borobudur University, Jakarta and Lecturer at Faculty of Law, Bung Karno \\ University, Jakarta
}

\begin{abstract}
The discussion on the form of comparison of child adoption from the perspective of Islamic law, western law, and customary law, also regulation no. 54 of 2007. Procedures for adoption of children alleged various perspectives from Islamic law, from Western Law, and customary law. The problem of adoption in various perspectives will provide clarity which is strengthened by regulation no. 54 of 2007. It will also provide convenience and relief for all people in Indonesia who want child dedication. From the comparison of the adoption point of view essentially has one purpose to give the right to the child to get the future feasibility of the child in accordance with custom, law and rules.
\end{abstract}

Keywords:Comparison of adoption, adoption pupose , adoption feasibility

DOI: $10.7176 / \mathrm{JLPG} / 84-09$

Publication date: April $30^{\text {th }} 2019$

\section{Introduction}

The problem of adoption is often a question in the community, both from the village level to the city or around the adoptive family. The reality in the field that there are still some families in marriage does not necessarily produce children, so in the end the family really wants children. This has been since ancient times until now the problem and the way of adoption is often the status of the child is only recognized not clear the legal status. This is considered normal nor does it see the rights of future children. According to customary law, adoption is a legal act that gives a position to someone else's child who is the same as a legitimate child.

An interesting requirement to discuss is the issue of adoption of children, so adoption of children becomes important because the number of people who want children, whether they are guided by their livelihood, or become foster children who are nurtured so that they enter a healthy and good family environment. The problem is how is the community or for families who want the adoption of children, just as long as they do not know from what point they want to adopt children. Besides that, there are some people who think that the adoption of children from families who have many children and from the economic side is usually difficult without rules which is important to reduce the economic burden since childhood the child may be nurtured, cared for and raised and regardless of the legal rules.

Traditionally, even if you have taken someone else's child, some people think that if you raise your child or someone else, the family that has not given birth to children can infect children without thinking about all risks and in terms of law that is not prepared. An interesting question is how Islamic law, customary law and western law regulate the adoption of children in Indonesia.

\section{Problems formulation}

a. What are the ways of Indonesian people in adopting children?

b. What adoption is legally valid and legally valid?

\section{Research Objectives}

a. The discovery of ways of adopting children by the Indonesian people partially and legally in force in Indonesia.

b. The discovery of legitimate observations based on rules that already have legal provisions that remain from the court by the judge.

\section{Benefits of Research}

a. Theoretically

Can be used for the development of legal science within the academia and related institutions.

b. Practically

Can provide donations and input for government and private institutions from the legal aspect.

\section{Research methods}

In the research and discussion used is the normative juridical method with descriptive analysis approach. 


\section{Research Result and Discussion}

\subsection{Understanding of children}

Children are national assets that will continue the ideals of the nation's struggle for the future. It is natural that children should be considered because the successor generation of this nation also depends on the children who currently exist. The nation can be destroyed because the nation's children are not paid attention to in the future.

According to Article 1 paragraph (1) of Law number 3 of 1997 concerning Juvenile Courts, children are people who in the case of a bad child reach the age of 8 (eight) years but have not reached the age of 18 (eighteen) and have never married. Whereas according to article 1 paragraph (2) of Law Number 4 of 1979, LN.1979-32 concerning the welfare of children, a child is someone who has not reached the age of 21 years and has never married. The Labor Law Act No. 12 of 1948 Article 1 Paragraph 1, children are men or women aged 14 years and under. According to customary law, it is determined that the size of a person is grown not from his age, but the size used is that he can work alone, capable of doing what is required in the life of the community, can take care of his own wealth. According to customary law a person is said to be immature when not married, and standing alone is not independent of parental responsibility. In Act No. 23 of 2002, Article 1 paragraph 1 concerning child protection determines that a child is someone who is not 18 (eighteen) years old including a child who is still in the womb. It is also explained in accordance with the Law of the Republic of Indonesia, No .35 of 2014 Article 1 paragraph 1, a child is someone who is not yet 18, including a child who is still in the womb.

According to Yusuf Qardawi, the child is the secret of parents and privilege holders, when parents are still alive, the child is the winner and when he returns to mercy, the child is the successor and symbol of immortality. The child inherits the signs of good parents hemisphere of heart and cut of liver.

Of the several notions of children that have been discussed it is clear that the child is a descendant that must be preserved for the continuation of the offspring both specifically and broadly. Specifically a descendant in the family, the child is a young generation as a human resource as a potential leader of the nation and has a role for a country that needs mentoring and protection mentally, physically, socially, in harmony with education according to its nature.

\subsection{Definition of Adoption}

Based on customary law, adoption is a legal act that gives a position to someone else's child who is the same as a legitimate child. Regarding the adoption of children, it is formulated by Government Regulation number 54 in 2007 , concerning the implementation of adoption. It was explained that adoption or adoption of a child is a legal act that transfers a child from the environment of the parent's authority, legal guardian or other person responsible for, care for, education, and raising the child into the family environment of the adoptive parents. Islamic teachings on adoption or adoption of children are called the Tabanni term, in this case to mention a custom that applies to the people of jahiliyah and the beginning of Islam. This means that if someone appoints someone else's child as his own child, then the child is entitled to the right that applies to his own child (Muhammad al-sayis, tt.IV.7). According to Ali as Sabrani's view, the adoption of a child can be permitted by Islam, if the adopted child is decided on his relationship with his father as biological parents which is then attributed to another father (adoptive father).

According to Zakiayah Daradjat (1995: 11,139), the validity of the adoption of children only occurs when the act is an impulse to help and help a child. This is a commendable act as long as it does not make the child's position like his biological child. According to Irma Setyowati Soemitro (1990: 38) the act of adopting children is to be carried out in the context of child protection. Motivation for the adoption of children must really be considered, whether it is true for the sake of the child who is the reason. In general, adoption can be interpreted as someone else's child who is taken and likened to the child himself, so that between the children who are appointed and by taking adopted children a legal relationship will arise.

\subsection{Adoption of Children according to Islamic Law}

Adoption according to the version of Islamic law we actually know at the time of the Prophet Muhammad at that time and became the customary habits of Arab society at that time. This was done by Rosululah before the Prophethood, when he adopted Zait bin Harisah. It turned out that Islam forbade the practice of adoption, which gave the position of biological children and decided nasab the original master. This is explained in Aquran surat al-Ahzab (33) verses 4 and 5 as follows: "Allah did not make two hearts in one human cavity." He also did not make your wife you zihar, as your biological mother. He also does not make your adopted child you say. Allah determines the right. Allah gave the right instructions. Adore them with their father's name, that is fairer according to Allah. If we don't know their fathers, they are your own brothers in the religion and your servants that you have liberated. And it is not a sin if you are wrong to call his father, but sin is what you deliberately do with your heart and intentions. And Allah is Forgiving, Most Merciful. From the explanation of the above paragraph an explanation can be taken, namely:

a. Adopting is a deception before Allah and before humans. Only a mouthful, which is not possible to cause 
true affection as in the real family.

b. Adoption is only words that do not show the truth and only mix the descendants who separate the original descendants and cause the wrath of God. This is in accordance with the hadith which reads: "Whoever claims Father is not his own father or gave himself to another family, he will get curses from Allah, angels and fellow humans: Allah will not receive from him later on the Day of Judgment, repentance is redeemed ( Imam al Bukhairi: tt.IV: 1947).

c. Adopting a child is often used as a way to work for the heir and his wealth. Thus it closes the possibility of you and other heirs and children as heirs. The Word of Allah the letter an-Anfal (8) verse 75 which means: "Those who believe and after that and emigrate, and fight with you, they are your class too. People who have blood relations are more suitable to help each other and protect, as contained in the book of Allah, Allah is very knowledgeable of all things.

d. Adoption by applying its status to biological children, sometimes becomes a burden for the adoptive father's family, if the adoptive father dies, then his family is responsible for providing him with a living. This causes the deployment of duties to the family with absolutely no blood relation with the adopted child (Fuad Muhammad Fahrudin (1985: 61 -67). Provisions show "inability" to adopt children, but there are some conditions which are revealed by several conditions expressed by some scholars.

If the opportunity to break the blood with his biological father, for example, all the benefits will be neglected and mix with the offspring and the favors will disappear. Allah created man with nation and tribe (Mahmud Syaltut, $\mathrm{tt}:$ 324). The adoptive child may be transferred to his foster father and he does not have inheritance rights from his inheritance. Likewise the children of the members are not forbidden to be married by their foster father (Ahmad Azhar Basyir, tt: 124-125).

Whereas if Islam cancels customs adoption following their legal consequences, Islam encourages people who want to care for, care for others to worship Allah SWT, such as caring for orphans and abandoned children who are treated like their own children, receiving physical care, education, and teaching and receiving outpouring of affection like parents themselves, without being separated from their biological parents, so do not do sexual relations with their adoptive father. Islam commands the support of neglected children and orphans who are known to be nasab or unknown, through foundations, orphanages or entrusted to Muslim families who can be trusted to nurture and educate them (Chusaimah T. Yanggo and Hafiz Ansory , 199; 124). Adoption in Islam is merely the transfer of the responsibility of caring for the child from the parents even to others both concerning education and fulfillment of daily needs. This is confirmed in article 171 (h) compilation of Islamic Law (KHI): "Children are children in maintenance for their daily lives, both education, and the transfer of responsibility from biological parents to adoptive parents is based on court decision (Abdul Ghani Abdullah, 1994: 30). Adoption in Islam focuses more on awareness of social solidarity which is an attitude of willingness, sincerity of someone to take over the responsibility of caring for children to ensure their life, education and their future needs, which is due to the awareness of disadvantaged parents or the child in an orphaned and even abandoned state. The motivation of adops in Islamic Shari'a is more focused on social functions and adoption actions do not cause legal consequences in the form of changes and transfer of positions in the heir between adopted children and adoptive parents (M. Yahya Harahap, 1993: 97). Morally, adoptive parents are required to provide mandatory grants or wills in part of their inheritance for the welfare of adopted children, while the amount is $1 / 3$ of the total inheritance of the heir

\subsection{Adoption in Customary Law}

The problem of adoption has long been known and done by people in various places in the world that are both primitive and advanced society. In Indonesia, the appointment of children is of many kinds and variety of the system. This adoption of children is based more on blood relations, so that the continuation of the family who attend the deployment depends on the person concerned. About the assets of the child concerned there is also a dependence on the relationship of blood relations or not. The demographics regarding the position in the community are still influenced by certain treatments and considerations.

a. How to appoint customary law in Indonesia.

This can be explained from various habits and certain areas. In general, customary law in Indonesia is different from Western law which is individualist liberarlis. According to Prof. Dr. Soepomo, Indonesian customary law has the following features:

b. Having a strong sense of togetherness or communal, meaning that people according to customary law are creatures in a close social bond, it seems that this togetherness encompasses all fields of customary law.

c. Has a religious style - magical that is related to the view of life of the industrial world.

d. Customary law is overwhelmed by the thoughts of concrete conclusions, meaning that customary law is very concerned about the number and repetition of real life relationships.

e. Customary law has a visual nature, meaning that the legal relationship of Dainggap only occurs because it is determined by a bond that can be seen.

The elimination of the issue of child adoption has the same characteristics between various jurisdictions even 
though the characteristics of each particular region color diversity among Indonesian ethnic groups.

a. There is no provision for anyone who is permitted to adopt and has an important age limit of 15 years, this is from the information:

1) Based on information from the Banjarmasin District Court.

2) In Singaraja Sub-district, Garut Regency, a woman who has never married cannot adopt, but widows / widowers are allowed.

3) In Leuwidamar Subdistrict (Bandung) it is good or not.

4) In Banjarharjo Subdistrict, Semarang daera in the Parindu Region of West Kalimantan (Dayak Pandu Tribe) is also permissible, but only with nieces.

5) In Sambas Sub-district (West Kalimantan) except in Manjuke Subdistrict, the unmarried person can only maintain a child.

\subsection{Adoption in Western Law (B.W).}

a. The Civil Code or Bugelijke Wet Book (BW) does not recognize adoption issues which are regulated in BW. BW in adoption or adoption of children outside of marriage, namely with BW book I Chapter XII part III article 280 to 290 . This provision may be said to have nothing to do with adoption because the Civil Code does not recognize adoption, so for the Dutch up to now not can appoint legally. Only known in Book I title 12 Article 227 NBW, stated:

b. Adoption occurs because of a court decision upon request (request for a couple who wants to attach a child.

c. However, in the Netherlands alone, the Staten General has recently accepted a law on adoption. The basis of his thinking is the emergence of a new human group in Europe, namely:

1) Parents who have lost children and no longer have children.

2) Orphans who have lost their parents who died in war.

3) The birth of many children outside of marriage.

4) These are the bases that encourage the General's statute to accept both the adoption law (Adoptie Wet) which opens up limited possibilities for adoption.

\subsection{Adoption in Western Law.}

a. Since ancient times the act of raising children has been known in various countries around the world the adoption of children is carried out by a primitive society, on the basis of blood relations, resulting in an artificial family. With the making of this artificial family, even strangers can be applied as a family member. Many methods are used for this, and the famous ceremony is the presentation of blood.

b. Adoption is a human act including civil actions which are part of family law so that it involves issues in human relations.

c. Adoption institutions will keep abreast of developments in society that continue to move towards progress and constitute a demand for the Civil Code that does not regulate adoption issues.

d. In finding the demands of the community, the Dutch government in 1917 issued the Statute no. 129 article 5-15 in the adoption arrangement. For the Chinese community in 1917 no.129, it is the only complement to the existing Civil Code / BW, thus the adoption problem according to the Western version must only depart from the Staatsblad.

e. Adoption Development in Western Law.

1) Warming of children has been known by various countries since ancient times have been known and carried out the adoption of children to obtain a position in primitive society, on the basis of blood relations an artificial family arises. Foreigners in the family can be counted as family members. Based on the famous upaara habit is the presentation of blood.

2) Adoption is a human act including civil warfare which is part of family law and involves human relations problems.

3) The existence of community development adoption institutions also adjusts towards progress and is a demand against the Civil Code that has not been regulated therein.

4) The existence of public demand, the Dutch government in 1917 issued Staatsblad no. 129 articles 515 which regulate the issue of adoption of children. Against the Chinese community. Thus the regulation is one of the supplementary rules of the Civil Code so that adoption must be guided by the existing Staatsblad.

f. May be adopted and may be adopted

1) In Statute Book of 1917, no.129 in Article 5ayat 1, it is stated that the attack of a man with a wife or married wife does not have a legitimate son in the male line, either descendants due to birth or descent due to appointment, may appoint a son - male as his child.

2) In paragraph 2, it is said that the adoption of a child must be carried out by a man together with his wife 
or if he does it after his marriage is dissolved by himself. Paragraph 3, stated, if a widow does not marry, again, and her husband who has passed away does not produce a child like verse 1, then he may appoint a man as his child.

3) From the existing provisions, those who are allowed to raise children are a husband and wife who are not sons, a widower who does not have a son or a widow who does not have a son from whom the widow is not left behind in the form of a will from her husband who states do not want to appoint children.

g. Article 6 and 7 regulate who is adopted.

Article 6 states that those who are allowed to be appointed are only male Chinese men who are not married without children, and have not been appointed by others. Article 7, paragraph 1, said that the person appointed must be at least 18 years younger than the age of the husband and at least 15 years younger than the wife or widow who appoints him. Whereas paragraph 2 states, that if the person appointed is a blood family, both legal and family outside of marriage, then the family because of his generation to the ancestors of the two parties together, must obtain the same degree of descent as the offspring, before being appointed.

The purpose and expectation of adoption from article 15 paragraph 2 is guided by adoption, namely, that the appointment of girls and appointments by making authentic certificates is null and void. There is a Chinese customary belief that boys will continue their offspring in the future and boys can maintain ancestors.

Another motive in adopting a child is that it is useful for members who are motivated by trust, that by raising a child, they think that the one who raises them will get their own child.

Appointment of Children

Arrangement regarding adoption of children based on Law no. 54 of 2007 in article 7 said that the adoption of children consists of:

a. Appointment of children between Indonesian citizens and,

b. Appointment of children between Indonesian citizens and foreign nationals.

Appointment Ana Ana Indonesian citizen.

In this case include:

1. Appointment of children based on local customs and

2. Appointment of children based on laws and regulations.

Child adoption is based on local customs, namely the adoption of children in a community that is clearly still practicing customs in social life. Whereas the appointment of children based on local customs can be applied for court decisions. Child adoption based on legislation

- the law covers the appointment of children directly and the adoption of children through childcare institutions. Child adoption based on legislation is carried out through the establishment of a court.

The conditions for adoption of children, in article 12 are regulated as follows:

1. Requirements for children to be appointed include:

a. Not yet 18 years old

b. Is an abandoned or abandoned child.

c. Being in family care or in childcare institutions.

d. Requires special protection.

2. The age of adopted children includes:

a. The child is not yet 6 years old, is the main priority.

b. A 6-year-old child reaches 12 years of age, as long as there are urgent reasons.

c. 12-year-old child reaches 18 years old, as long as the child has special protection.

In Article 13, the adoptive parents must fulfill the following conditions:

a. Physically and mentally healthy.

b. The most rending age is 30 years and the highest is 55 years.

c. Diverse with the religion of prospective adopted children.

d. Be good and have never been convicted of a crime.

e. Married status is at least 5 years.

f. Not a similar partner.

g. No / do not have children or only have one child.

h. In economic and social conditions.

i. Obtain children's consent and written permission of the parent / guardian of the child.

j. Make written statements that the adoption of children is in the best interests of children, welfare and child protection.

k. The existence of a local social worker social report.

1. Has taken care of the most prospective adopted children 6 months, since parenting permission is given.

m. Obtain ministerial and head permission from social institute 


\subsection{Sisitem Appointment of Children.}

The appointment of many children to the system that is carried out depends on local customs where each nation has its own customary law. In this world there are various ways to raise children. This is the way of adopting children from various countries and also in Indonesia in particular.

1. How to appoint children in various countries.

Presented by Muderis Zaini, S. H as follows:

a. In the Encylopedia of Relegion and Ethics, it is known that the people of Leogea and New Guinea, sometimes their tribal leaders can save their souls by adoption, by sex and age, may be considered as father, mother, brother or child. Then there is also the adoption of a child by a mother who does not have children or a small family or maybe the family only has only daughters or boys.

b. In the residents of Osage and Kansas in North Amirika, they take boys or girls as children, grandchildren or nieces if they have died and are sought to find similarities.

c. Crantz describes the Eskimo's habits, Greenland, as the reason for raising children is if a family is not or only few children, then the husband of the family raises one or two orphans as their adopted children. Adoption for them aims to help find food or as a family in charge on the next day. The Eskimos in Behring Strait who do not have children usually raise daughters or, more preferably, boys who are expected to carry out the festival at their death. The Baronga tribe in Delaroga bay, if the head of his tribe dies, while he does not have a son, then the village is considered to be gone and his name is damaged and has a bad luck. By raising a boy, return the fragrance of the name of the chief. The zulu tribe describes adoption as giving worship services in death. In Cambodia the ceremony regarding the adoption of children is called Solem Ceremony.

d. In Japan the matter of adoption was not original teaching, but was first introduced from China with political objectives during the reign of Hojo Regents (1205-1333). In this country the family is more important than the individual. The problem of inheritance, adopted children can play an important role, while religion is no one to question the issue of adoption. Then if the adoptive father dies, then the adopted child is in charge of the event according to his religion, Shinto, Buddhism or ancestral religion. The existence of the child detention service is not needed, but is required to report to the "public office".

\subsection{How to appoint children in Indonesia.}

Child empowerment in Indonesia does not have much difference with child training in various other ethnic groups. In general, customary law in Indonesia is different from liberal individualistic Western law. Customary law in Indonesia has the following features:

a. Having a strong sense of togetherness or communal, meaning that humans according to customary law are creatures in a close social bond, it feels like this togetherness covers the entire field of customary law.

b. It has a religious-magical style that is related to Indonesia's natural view of life.

c. Customary law is overwhelmed by the thoughts of concrete arrangements, meaning that customary law is very concerned about the number and repetition of concrete relationships of life.

d. Customary law has a visual nature which means that legal relations are considered only because they are determined by a bond that can be seen.

Thus, especially the problem of adoption of children has the same characteristics between various jurisdictions, although the characteristics of each particular region color the diversity of cultural ethnic groups in Indonesia.

Thus it can be explained as follows:

1. There is no provision regarding anyone who can adopt and limit their age, except for a minimum of 15 years. This is based on information obtained from the Banjarmasin district court. In Singaraja sub-district, Garut regency, a woman who has never married cannot adopt, but widows or widowers are allowed. While in Leuwidamar Subdistrict (Bandung) either not yet married or not. In Banjarharjo Subdistrict, Brebes (Semarang) in the Parindu area of West Kalimantan (Dayak Pandau Tribe) is also permitted, but in a nephew relationship. In Sambas Sub-district (West Kalimantan) except in Manyuke, Menpawah sub-districts, unmarried people may only raise a child called Agonahain not in the sense of raising a child. Other areas of Kendari, Southeast Sulawesi, have not found unmarried people to raise children, as well as in the Kaloka area, except widows / widowers. In Central Lombok, it is not known or has never been a bachelor to raise a child. In Indonesian Indigenous Peoples it does not distinguish whether boys or girls except:

In the Leuwidamar area, girls cannot be adopted as adopted children. Also in Kupang Regency Alor, Lampung Peminggiran Kedondong District, because the community adheres to a male lineage (Patrilineal). Related to the age used as adopted children is different, for example: a. In the garut district, the age used as adopted children is under 15 years old and can also be over 15 years as long as it is not married. In Cikajang Subdistrict usually the children who are appointed are still babies until they are 3 years old. c. Then in the Parindu area of West Kalimantan, a child can begin to be appointed as an adopted child usually after the child is released from his 
mother's milk. d. In Sambas sub-district does not determine the age limit, but the feasibility factor that must be considered, namely the age of the child who is appointed and the parent who raises must have the appropriate difference as a child with his own parents. e. The environment of the Malay community in the Pontianak area, usually the adopted child is a child who is only 40 days old and the largest is 5 years. f. In Kendari subdistrict, generally children are adopted from 1 to 6 years of age. g. If in some areas in Kolaka Regency, the age of the adopted child was taken from childhood, when the child was not fully aware of his real master. On the other hand, if in Central Lombok, even people who are already grown up can be taken as adopted children there with an acon. In contrast to Kupang and Alor Regencies for the Rote tribe, the maximum age of children is 2 years, even for the Timorese tribe of Tidore (Ambon) district, the age limit is not specified, but one area is unique, where there is a child who is still in the womb an agreement has been made by the one who appoints the parents who are pregnant to be adopted children. For some in the West Irian region there are also children who are grown / grown up as adopted children because he is a merit. In Central Aceh regency there are also adults, and even married when they are not more than 20 years old.

\section{Conclusion}

From the reviews and discussions described above, the following ways can be adopted for child adoption in Indonesia. In Islamic law the procedure for adoption of children is permissible even if it does not change the status or status of children from biological parents to adoptive parents. Furthermore, Islam strongly encourages the adoption of children so that children can be protected by the dignity of their lives which can guarantee survival. While adopted children can live their lives and can be given a will amounting to no more than $1 / 3$ of the total inheritance.

a. From the adoption of Western law.

In the case of adoption by Western law, it can be done with the appointment of the community on the basis of blood relations so that an artificial family arises, so that foreigners can be applied as one family member.

Adoption is a civil act and part of family law, and the institution always follows developments that are not regulated in the Civil Code. As for the adoption of children between Indonesian citizens based on the prevailing laws and regulations.

b. Customary law adoption:

By customary law, if in the country of Indonesia there are many kinds and varieties of the civilization system. The adoption of many children is based on blood relations. Likewise the problem of the assets of the child concerned is also dependent on and affected by the treatment of blood relations or not. Also about the position of children in the community is still influenced by certain treatments and considerations.

There are still many ways of adopting children in Indonesia that still use a customary law system that varies greatly. The legal force of adoption has not traditionally been legally enforceable as long as it has not been ratified in accordance with applicable legal procedures.

\section{References}

Djaja S, Adopsi (Pengangkatan Anak) Dalam Yurisprudensi, , Tarsito, 1996,Bandung.

Hilman Hadikusuma, Hukum Adat Dalam Yurisprudensi, Cita Adi Bakti , Bandung,1993.

Djaja S.Meliala , Perkembangan Hukum Perdata tentang Orang dan Hukum Keluarga, Penerbit Nuansa Aulia, 2015.

Irma Setyowati Sumitro, Aspek Hukum Perlindungan Anak, Bumi, Aksara ,1990.

R. Soeroso, Perbandingan Hukum Perdata, Sinar Grafika, bandung, 1992.

Law

Amandamen undang-Undang Perlindungan Anak, No.35 tahun 2014, Sinar Grafika, Jakarta, 2015. 